\title{
The Development of E-Book-Problem Based Learning Media
}

\author{
$1^{\text {st }}$ Charles Fransiscus Ambarita ${ }^{1}, 2^{\text {nd }}$ Rotua Sahat Pardamean Simanullang ${ }^{2}, 3^{\text {rd }}$ Dita Eka \\ Pertiwi Sirait ${ }^{3}$ \\ \{charlesambarita@unimed.ac.id ${ }^{1}$, rotuaspsimanullang@gmail.com², \\ ditaekapertiwi1986@gmail.com $\left.{ }^{3}\right\}$
}

Study Program of Economic Education, Faculty of Economics, Universitas Negeri Medan, Indonesia $^{1}$, Study Program of Office Administration, Faculty of Economics, Universitas Negeri Medan, Indonesia ${ }^{2}$, Study Program of Business Education, Faculty of Economics, Universitas Negeri Medan, Indonesia

\begin{abstract}
Revolution 4.0 requires college students to be able to have skills in solving problems. The rapid development of technology and the outbreak of the COVID-19 pandemic require the learning process is done online. This is certainly very different from the face-to-face learning process before the pandemic era. The object of this research is Learrning Planning e-book based PBL. E-book developed using the Kvisof Flipbook Maker application. E-books are compiled and developed with regard to the material and media aspects. The validation results of the developed e-book viewed from the material and media aspects. For the material, material expert gives a value of $94.14 \%$ and categorized as very good. For the media, media expert gives an assessment of $88.5 \%$ and considered very good.
\end{abstract}

Keywords: Development, E-book, Learning Planning, PBL.

\section{Introduction}

Education is a crucial part of the civilization of a nation. A nation that has competitiveness is the result of a planned education in the long term. The development of technology in the era of the industrial revolution 4.0, which is commonly called the very fast information era are excellent tools to achieve high civilization and support in the world of education. Along with that, this development has been hampered because the world is currently being hit by a corona virus outbreak, including in Indonesia. Since February 2020, the corona virus pandemic has hit Indonesia.

The government responded to the high spread of the corona virus by releasing circular about online learning and working from home in order to prevent the spread of Covid-19 [1]. One of the things contained in this circular is to replace face-to-face learning with networkbased learning (online) through e-learning used by various educational institutions. Medan State University as part of educational institutions in Indonesia, also applies the same thing, namely implementing online learning starting in March 2020.

Lecturers as the spearhead of learning in the classroom are required to be able to develop online learning media. Learning tool such as Semester Learning Plan (RPS) are designed according to the online learning that will be implemented. Online learning media is a tool for 
lecturers to deliver learning materials that can stimulate the minds and wills of students in the learning process. Learning media requires students to take an active role in learning and use media as learning device and by changing student behavior in the teaching and learning process [2]. One of the online learning media that can be developed by lecturers is e-book learning media.

Digital book or also called e-book, is a publication that consists of text, images, sounds and published in digital form that can be read on computer or other electronic devices such as android, or tablet [3]. This can be interpreted that e-book or digital book is a copy of the concept of teaching materials that are poured by lecturers digitally in the form of text, images, sounds and others that are packaged interactively to increase the enthusiasm of learning from students. Using this e-book, students are expected to be more active in learning and create new variation of learning where so far the conventional way of learning is through printed books or dictation. The e-book in this study uses the Kvisof Flipbook Maker application. Kvisoft Flipbook Maker is a suitable software when used as a learning media because in this application it is possible to add various features such as motion animation, video, images, and audio that can be interactive learning media so that it can attract students' interest and make teaching and learning activities not monotonous [4]. The selection of Kvisoft Flipbook Maker is the right choice and in accordance with the characteristics of Learning Planning course, where Learning Planning course is dominated by theoretical concepts. In this Kvisoft Flipbook Maker software there are several features to add hyperlink, images, videos, and audios. So that with this feature it is able to make it easier for students when they will understand material related to technology videos in the world of offices in the current digital era [4].

One way to improve student learning outcomes is to train how to solve problems in course studies. Problem Based Learning (PBL) is a learning approach that starts with posing a problem and continues by solving the problem [5]. With problem solving skills, students, both in groups and individually, will be able to think critically and creatively so that mastery of lecture material can be achieved as a whole and comprehensively. The concept of the PBL method begins with identifying problems in learning and then making observations either in the classroom or out the classroom to be able to solve problems scientifically.

Based on the background of the problems described above, the problem that becomes the study material in this research is how do lecturers develop learning media with Kvisoft Flipbook Maker application based PBL on Learning Planning course? The purpose of this study was to produce learning media with Kvisoft Flipbook Maker application based PBL on Learning Planning course.

\section{Method}

This research is a research and development $(R \& D)$ research, which is a type of research that produces a product instead of testing a theory. Sugiyono stated that research and development is a process used to develop and validate educational products, test the effectiveness of these products, and can be accounted for [6]. This research will produce an ebook based PBL in Learning Planning course.

The model used in this study is 4D (four-D models). On the other hand, Sugiyono stated that four-D model consists of 4 main stages, namely: 1) define, 2) design, 3) develop, and 4) dessiminate [6]. In this study, only the develop stage was carried out, the dissemination stage was not carried out due and time constraints. 
The instruments used in this study were validation sheets and interview. Interview was conducted as a preliminary study for data collection in exploring the problems to be studied.

The research data were analyzed to determine the feasibility (validity) of Learning Planning e-book based PBL. The validity of the e-book can be seen from the validation sheets filled by the expert and the results of questions and answers during the validation process.

\section{Results and Discussion}

\subsection{Define Stage}

This define stage is carried out by analyzing several things, namely: (a) curriculum analysis: the curriculum analysis is the Indonesian National Qualifications Framework (KKNI) curriculum which consists of 9 levels of academic qualifications. This curriculum analysis is carried out by analyzing competency standard and basic competencies in the Lesson Planning course. The results of the analysis of competency standard and basic competencies become the formulation of learning indicators; (b) student analysis is analyzing student characteristics including age, motivation, background knowledge of students, academic abilities, and social skills. Furthermore, psychological changes that occur such as efforts to find identity, future aspirations begin to arise, freedom to do something. The role expected by students in social groups in the community where students interact. This creates problems for students, in the form of changing interests, behavior, and values in life. In adolescence, students act without worrying about the risks posed both to themselves and to others; and (c) concept analysis: concept analysis aims as the basis for the main concepts that must be mastered by students in the learning process. In the concept analysis, identification and formulation of the main concepts will be compiled in the material in the Learning Planning e-book based PBL, and (4) needs analysis includes the need for Learning Planning ebooks based PBL of $86.66 \%$.

\subsection{Design Stage}

At this stage, there are several activities carried out such as: (1) establish basic competencies and learning objectives and (2) designing learning media. The determination of basic competencies and learning objectives that will be developed in e-book media is the result of discussions and various considerations with Learning Planning course lecturers. Designing learning media is carried out by making an overview and design of an e-book for Learning Planning course that will be developed. This stage includes the design of display as well as the material that will be displayed in e-book media including the selection of introductory images, supporting videos and exercises that are in accordance with the material and purpose of making e-book.

\subsection{Develop Stage}

At this stage, there are 2 activities carried out, namely: (1) media production and (2) product validation. The production of e-book learning media adapted to designs that have been made previously. The e-book was created using Kvisoft Flipbook Maker application by including images and videos to support the learning. The material displayed is a summary of 
the material on the chosen topic so that it is easier for users to understand. The product validation consists of two validation stages, namely material validation and media validation. Material validation is carried out by material experts, the aim is to get an assessment from material expert regarding to the material presented. Meanwhile, media validation is carried out by media expert with the aim of getting an assessment from media experts regarding the developed media. The data was obtained through validation sheets given to the experts. The data obtained from each expert is collected and then processed into quantitative data, then the average data is sought. The average result determines the quality of the developed e-book. Suggestions and inputs from each expert are used as a guideline to make revisions or improvements to the developed e-book learning media.

The validity (feasibility) of the Learning Planning course e-book based PBL was validated by an expert, namely an material expert. The results of the expert validation on the e-book of Learning Planning material based PBL on the component aspects were obtained at $93.75 \%$. Meanwhile, the results of expert validation from the aspect of the feasibility of the substance obtained a value of $94.54 \%$ with a very good category.

Table 1. The results of the validation of the Learning Planning e-book based PBL on the material aspect.

\begin{tabular}{lcc}
\hline \multicolumn{1}{c}{ Assessment Aspect } & Percentage of validator rating & Category \\
\hline Eligibility of the e-book & $93.75 \%$ & Very good \\
component & $94.54 \%$ & Very good \\
Eligibility of substance & $\mathbf{9 4 . 1 4 \%}$ & Very good \\
Average &
\end{tabular}

The validity (feasibility) of the e-book on the media aspect of teaching materials is validated by the learning media experts. The results of the expert validation on the Learning Planning course e-book based PBL on the visual communication aspect were obtained by $87 \%$ and the characteristic aspect of the e-book obtained by $90 \%$.

Table 2. The results of the validation of the Learning Planning e-book based PBL on the media aspect.

\begin{tabular}{lcc}
\hline \multicolumn{1}{c}{ Assessment Aspect } & Percentage of validator rating & Category \\
\hline Visual communication & $87 \%$ & Very good \\
Characteristics of e-book & $90 \%$ & Very good \\
Average & $\mathbf{8 8 . 5 \%}$ & Very good \\
\hline
\end{tabular}

The product developed in the form of an e-book in the Learning Planning course based PBL was compiled and developed with regard to the material and media aspects by using the Kvisof Flipbook Maker software or application so that college students of the Economics Education study program could read like reading a textbook physically because there are sounds, images, letters and animation effects with a touch of technology. The e-book is designed based PBL so that college students can practice critical thinking skills and mastery of Learning Planning courses can be carried out as a whole and comprehensively. The developed e-book learning media has met the valid word. The fulfillment of a good validity aspect is in line with the opinion expressed by [7] which states that the validity aspect refers to the extent 
to which the device design is developed. The e-book learning media developed has gone through a validation process by the validator. The results of the material expert assessment of the Learning Planning e-book based PBL on the material aspect obtained an average value of 94.14\% with a very good category. Then the results of the assessment of the media expert validation media aspect obtained an average value of $88.5 \%$ with a very good category.

\section{Conclusion}

This research and development aims to produce an e-book of Learning Planning course based PBL developed through the 4D model (four-D model). The developed e-book obtained a very good category both from the material aspect and the media aspect.

The development of the Learning Planning e-book based PBL is expected to make students understand the Learning Planning course material as a whole and comprehensively so that learning outcomes can be fulfilled.

\section{References}

[1] Makarim NA. Surat Edaran Menteri Pendidikan Dan Kebudayaan Nomor 4 Tahun 2020. Indonesia: Menteri Pendidikan dan Kebudayaan Indonesia; 2020.

[2] Peprizal SN. Pengembangan Media Pembelajaran Berbasis Web Pada Mata Kuliah Fisika Modern. J Ilmu Pendidik dan Pembelajaran. 2020; 4(3):455-467.

[3] Mentari D, Sumpono S, Ruyani A. Pengembangan media pembelajaran e-book berdasarkan hasil riset elektroforesis 2-d untuk mengukur kemampuan berpikir kreatif mahasiswa. PENDIPA J. Sci. Educ. 2018; 2(2):131-134.

[4] Fitri ER, Pahlewi T. Pengembangan LKPD Berbantuan Kvisoft Flipbook Maker pada Mata Pelajaran Teknologi Perkantoran di SMKN 2 Nganjuk. J Pendidik Adm Perkantoran. 2020; 9(2):281-291.

[5] Siswono TYE. Upaya Meningkatkan Kemampuan Berpikir Kreatif Siswa Melalui Pengajuan Masalah. J Pendidik Mat dan Sains. 2005; 10(1):1-9.

[6] Sugiyono. Metode Penelitian Kuantitatif, Kualitatif, dan R\&D. Bandung: Alfabeta; 2013.

[7] Sofia A. Development \& Learning Models in the 2013 Curriculum. Jakarta: PT. Library Achievement; 2013. 